\title{
AChieving Sustainable Development Through VAlue CHaIN
}

\author{
Abid Sultan ${ }^{1}$ and Dr. Saurabh ${ }^{2}$ \\ ${ }^{1}$ Research Scholar, College of Management, Shri Mata Vaishno Devi University, Sub \\ post office: Katra, Jammu \& Kashmir- 182320 \\ E-mail: abidsultan2012@gmail.com \\ ${ }^{2}$ Asst. Professor, College of Management, Shri Mata Vaishno Devi University, Sub post \\ office: Katra, Jammu \& Kashmir- 182320 \\ E-mail: saurabh.sriesmvdu.ac.in
}

\begin{abstract}
:-
In the last three decades globalization accompanied with technological developments, changing customer expectations - both in terms of demand and need, economic interdependencies of the nation's, growing environmental consciousness etc. had eventually forced business firms around the globe to be effective and efficient in every activity they perform and had accordingly gave birth to the various business models. Initially focus of the business models as well as strategies was somewhat restricted towards the "Sustainable Competitive Advantage" but as the ambit was enlarged focus shifted towards the "Sustainable Development". The paper focuses towards the sustainable development through the lenses of value chain in a holistic manner by identifying the various parts of value chain, its contribution in identifying the dimension of sustainable competitive advantage, linkages involved in value chain and generic strategies, thereby, conceptualizing the value chain model as a strategy for achieving the sustainability competitive advantage and sustainable development.
\end{abstract}

\section{Keywords:}

Value Chain, Sustainable Competitive Advantage, Sustainable Development.

\section{INTRODUCTION:}

"Increasingly, government, civil society and special interest groups are holding business accountable for their negative environmental and social impacts, challenging the sustainability of corporate strategies built on self-interest and an insular view of the world and organizational impacts thereon." Fearne \& Martinez (2012)

The integrated impacts of ecology and social changes over business have forced the firms across the globe to adopt strategies that yield sustainable development. Sustainable development is posing so many questions to the firm's all over the world and infact presents an interesting and unique challenge to the firm's across the globe. Traditionally, the firms were concerned about internal efficiency and effectiveness of their activities only for ensuring profitability. Internal economic sustainability was the main goal of the companies. But now with growing concerns about the environment and changing business scenario firms are forced to think about their 
International Journal of Managing Value and Supply Chains (IJMVSC) Vol.4, No. 2, June 2013

activities in line of environment. The firms are re-orienting themselves so as to produce with efficiency and effectiveness but with less environmental impacts along their entire value chain for sustainability. Placet et al. (2005) defined sustainability along three dimensions- environmental stewardship, social responsibility and economic prosperity. Environmental stewardship focuses towards natural environment like air, water, land, and ecosystems as well as effectively managing the earth's natural resources. Social responsibility favors the equitable development of the employees (in terms of quality of life) as well as of the society as a whole. Economic prosperity aims at creating economic value and ensuring creation of economic opportunity for both the enterprise and its stakeholders. The 'Sustainable Development' favors the strategic fit between the internal economy of the companies and external socio-environmental impacts. It has become a success mantra for the firms not only for the present but as well as for the future.

\section{LITERATURE REVIEW}

Brundtland Commission report of 1987 through its report "Our Common Future" published by World Commission on Environment and Development, defines sustainable development as "Development that meets the needs of the present without compromising the ability of future generations to meet their own needs". Sustainable development is not a new phenomenon but is the gradual evolution of the events that shaped the growing consciousness about the environment. Also companies realization and recognition of the fact that sustainability of the companies lies not only in the profitability of markets/businesses/products but also lies in the sustainability of the people and planet, has added momentum to the literature of sustainable development (Tan \& Zailani, 2009).

Elkington (2006) argues that the three pressure waves guided the development of environmental agenda in the business arena - $I^{\text {st }}$ wave started in 1960's, $2^{\text {nd }}$ wave started in mid-1970's and $3^{\text {rd }}$ wave started in 1999. The three waves molded the orientation of the society as well of the firms towards the socio-environment consciousness. These waves also called the attention of the various international bodies like United Nations (UN), World Trade Organization, United Nations Climate Change Council etc. and their critical roles in balancing these socio-environment impacts. Thus, twenty first century witnessed the radical shift in the growing concerns for the environment and society protection from degradation and exploitation.

This new radical consciousness forced companies to measure their impacts on the environment and society. It engaged firms in triple bottom line approach (3BL) for reporting their natural resource usage like energy and other resources as well as reporting footprint they leave behind for the future generation (Kleindorfer et al., 2005). The new paradigm led to revisiting of the strategies and investing time and resources towards redesigning, developing and implementing strategies that favor environmental initiatives along the value chain as well as development of society \& people. Now environmental consciousness \& society development is no longer an optional strategy but a well thought and planned strategy that aims at sustainable development. Sustainable development is gaining momentum with each passing day but still companies are falling and struggling to achieve it.

Sustainable development is not the challenge for the companies but how to achieve it is the biggest challenge for the companies i.e. what strategies to pursue for sustainable development (Kleindorfer et al., 2005). There have been efforts from all the sections of the society for developing frameworks, strategies or policies for achieving sustainable development. Strategies like business process reengineering, total quality management, just in time, green supply chain, 
environment management systems etc. have been developed for achieving sustainable development either directly or indirectly .

However, in the process of developing \& implementing strategies for sustainable development companies have to adopt broad and holistic approach so that the formulated strategy should cover all three P's of sustainable development i.e. People (Society), Profit (Economy) \& Planet (Environment) (Beamonn 1999; Kleindorfer et al., 2005 and Tan \& Zailani, 2009). The strategy for sustainable development should be inclusive and should bring in efficiency, effectiveness and linkages in both internal \& external processes of the company. Also should built and improve competitive advantage \& competitive position in the long run. Porter (1985) provided for the food of thought to the researchers and practioners with the concept of Value Chain and Competitive Advantage.

Porter provided a systematic way of examining economic activities a firm as well as interaction of such activities for developing sustainable competitive advantage. Value activities of the firm are building blocks by which firms deliver products to the customer, earn profit/margins as well develope advantages over rivals. From strategic management point of view, the value chain disaggregates a firm into its strategically \& technologically relevant, distinct and important activities. These value activities do not operate in isolation but in a cohesive manner as an interdependent system which is related to each other through linkages. Value activities and linkages together lead to the competitive advantage. The linkages among the value activities in the value chain lead to the competitive advantage in two ways - (1) Optimization - a firm must optimize such linkages reflecting its strategy in order to achieve competitive advantage. (2) Coordination - reduces cost or enhances differentiation (Porter, 1985).VCA is a tool for examining the current state of the chain and identifying an improved future state (Fearne \& Martinez, 2012). The improved future can be achieved through strategic planning to maintain the scope and distinctiveness of the value chain as well as of the sustainable development.

\section{RESEARCH METHODOLOGY:}

The paper focuses on conceptual and theoretical approach towards the value chain, sustainable competitive advantage and sustainable development. The paper discusses the various dimensions contributing to the sustainable competitive advantage along the value chain. The paper provides the conceptual insights which needs to be further validated through empirical research

\section{DISCUSSION}

The triple bottom line approach of sustainable development strategy is making its place in every decision of the firm. The social responsibility, economical responsibility and ecological responsibility are taking the center stage in the strategic planning activity of an organization. In this scenario the biggest question that arises is how to manage the triple bottom line approach and thus accommodating the three pillars of sustainable development - what strategies needs to be implemented? The Value Chain Analysis provides an opportunity of learning and contributing in this regard. Value Chain primarily focuses towards the value creation, value activities and linkages. They integrate together to develop sustainable competitive advantage. The value chain linkage identification and managing helps in bringing the synergies along the value chain through coordination, trust building and relationship. Value chain approaches in a holistic and synchronizing manner for fulfilling the various responsibilities of the companies. The synergies developed along the value chain identify the value addition activities and thus eradicates other 
non-valuable activities. This reduces the excess resource usage and thus helps the organization to build the competitive advantage with available sources whether tangible or intangible. Competitive advantage can be built along the various dimensions like total quality management, knowledge management intellectual capital, organizational learning, product innovation etc. All these help the organization in bringing efficiency and effectiveness in the organization and thus, fulfill the economical responsibilities. The value chain as a strategy for sustainable development needs to be viewed through the perspective of strategic planning. One of the primary reasons for this can be that sustainable development is not a game play of short duration but a well thought provoking and planned game, which involves resources as well as time \& commitment.

As a framework of strategic planning value chain helps a firm to identify and build the competitive advantage by analyzing the various value activities and linkages along the entire value chain. Hergert \& Morris (1989) suggested that the three characteristics of value chain as an effective strategic planning tool are: (1) emphasis on identifying the source of sustainable competitive advantage (2) insistence on the importance of complex linkages and interrelationships (3) the identification of generic strategies which must be pursued consciously and coherently in the different value creating activities.

\subsection{Sources for Sustainable Competitive Advantage}

The Resource Based View of strategic management views firm's resources as "source" of a potential competitive advantage. Barney (1991) identified four resource attributes that can be understood as empirical indicators for any resource to be a sustainable competitive advantage resource must be valuable, imperfectly imitable, rare \& imperfectly substitutable. For the sustainable competitive advantage the tangible criterion is not a necessary requisite. Coyne (1986), suggested that for sustainable competitive advantage resources must have capability differentials and identified four types of capability differentials (1) Regulatory (2) Position (3) Functional (4) Cultural. Hall (1993) argued that intangible resources have capability differentials and which result in sustainable competitive advantage and superior firm performance. This provides for a framework to link intangible resources and capabilities to sustainable competitive advantage. This has given new directions towards intangible resources like employee know-how, product reputation, company reputation, ability to innovate etc. Thus, it can be understood that both tangible and intangible resources can be the source of sustainable competitive advantage.

However during last three decades, practitioners, academicians and researchers are in the process of identification of the dimensions that contribute to the sustainable competitive advantage. Some of these sources that have been considered as source of sustainable competitive advantage are mentioned below:

\subsubsection{Organization Learning:}

Organizational learning, and rapid product development, is the 'best' source of sustainable competitive advantage (Prahalad \& Hamel, 1990). Apple Incorporation is the most suitable example. Firm's ability to learn from its people \& networks of business relationships is an important source of sustainable competitive advantage. Learning thus evolves as a network of relationships which involves constellation of resource linkages among business partners tied together by interconnected resources (Eng, 2005). The challenge is how the organizations evolve the organization learning across the value chain. 
International Journal of Managing Value and Supply Chains (IJMVSC) Vol.4, No. 2, June 2013

\subsubsection{Knowledge based view of firm:}

Creating and utilizing knowledge are important sources of sustainable competitive advantage as knowledge sharing, integration \& transfer helps in innovating new product/services or bring efficiency and effectiveness in the existing ones. (Prahalad \& Hamel, 1990; Corso et al., 2001 and Nonaka et al., 2000)

\subsubsection{Human Resource:}

There has been a growing consensus among the academicians' researchers and practitioners towards the importance of human resource in an organisation. It is another source of sustainable competitive advantage (Wright et al., 1994). Sanz-Valle et al. (1999) provided empirical evidence towards the relationship between human resource practices and strategy.

\subsubsection{Intellectual Capital:}

Hayton (2005) defined the intellectual capital (IC) along the three dimensions - human capital, intellectual property and reputational capital. Major part of an organization's knowledge is embodied in its IC (Edvinsson \& Malone, 1997). Intellectual contributes to the sustainable competitive by encouraging innovation, improving decision making and creativity

\subsubsection{Supplier Integration:}

An organization is a network of different entities - supplier, channel partners and buyers. All of these entities are important for the sustainability of the firm. A good and prosperous relationship with all of them is very much essential particularly with suppliers Supplier relations are being recognized as important source for sustainable competitive advantage (Mudambi \& Susan, 1998). The dimensions like commitment and trust plays an important role in building and maintaining the supplier relations. Long-term relationships with suppliers often produce higher-quality or lower-cost inputs (Cusumano \& Takeishi, 1991).

\subsubsection{Total Quality Management (TQM):}

Savolainen (2000) also holds that a commitment to TQM can trigger an inimitable competitive advantage as it is difficult to imitate because of resource needed. Available literature on TQM highlights the four dimensions - customer focus, continuous improvements, employee fulfillment and organization as a total system. According to the Rose \& Ito (1996), TQM helps in the deployment of distinctive competencies at the heart of the organization like managerial competencies, employee know-how, external co-operation skills, creation of a collective mind, organizational commitment, reputation, speed \& flexibility etc.

The concepts discussed above give a reflection that sources for sustainable competitive advantage can be tangible as well as non-tangible. Value chain helps in identifying these sources as value chain analysis involves identifying value creating activities. The value creating activities are the building blocks for sustainable competitive advantage. Sources for the competitive advantage contribute to the sustainability of the firm if they are shared across the value chain with suitable linkages.

\subsection{Value Chain and Linkages:-}

Present complex business scenario accompanied with growing customer needs and expectations is making it difficult for the organizations to hold and maintain all the resources needed by the organization. Linkages provide a mechanism for resource sharing among the various players along the value chain. Linkages are very much important for mounting sustainable competitive 
advantage. Due to its intricate nature linkage identification and its management is a tough task. According to Porter (1985), linkages exist not only within the firm's value chain but between a firm's value chain and value chain of supplier's and channels - vertical integration. The proper management of all the linkages involved in the value chain be it value chain of supplier, value chain of channel partner etc. contributes towards harmonization of the value creating activities which creates less pressure on resources, creates economic opportunities as well bring valuable products in the society (market) and thus increases living standard of people \& quality of life. Linkages involve sharing of resources so that a value is created along the value chain through synergy, mutual understanding, commitment and trust. The synergy along the value chain is achieved because the relationship is not based on zero-sum game, where one entity gains at the expense of another but it's based on the commitment, trust and understanding focused towards the mutual gain of each other. The linkages are quite helpful in building the capabilities like organizational learning, knowledge creation etc. which can be converted into the sources of competitive advantage. Uzzi (1996) argues that embedded ties between the firms create an environment of trust and understanding which allow for the exchange of fine-grained information and joint problem solving. The benefits of the linkages in a value chain are numerous and it has been argued and empirically shown that the sources of competitive advantage may be found in idiosyncratic linkages and also innovative performance and supernormal profits (Dyer \& Singh, 1998; Gulati et al., 2000 and McEvily \& Zaheer, 1999). For an effective exploitation of the linkages firm needs strategies.

\subsection{Value Chain and Generic Strategies:}

Porter (1985) propounded three generic strategies - cost leadership, differentiation and focus strategy for sustaining and fighting the competition and competitors. The generic strategies cannot work in isolation. For their effective implementation they need resources and linkages. Resources provide the necessary inputs required while the linkage provides the necessary support for the generic strategies. The three generic strategies of Porter help in building competitive advantage but in different manner. The cost leadership and differentiation aims at a broader segment while as the focus strategy aims at the narrow segment. These strategies have been well acknowledged in the field of management as well as in strategic management both empirically and theoretically (Galbraith \& Schendel, 1983).

It is still a debatable issue that a firm's sustainability is dependent upon its competitive advantage. However it is confirmed that a firm operates in an industry as long as it has competitive advantage. Having a competitive advantage is not a static phenomenon. Rather it's a dynamic process so firm needs to constantly look for the strategies that help in identifying sources of competitive advantage. Value chain helps not only in finding the sources of competitive advantage but also helps in understanding linkage and the generic strategies for creating sustainable competitive advantage. It also helps in bringing efficiency \& effectiveness along the value chain so that internal economic stability and external socio-environmental responsibilities can be strategically fit together through strategic planning.

\section{Research Limitation and Implication:}

The paper provides a perspective in the field of sustainability - sustainable competitive advantage and sustainable development. The paper discusses the various dimensions contributing to the sustainable competitive advantage along the value chain. 


\section{Conclusion:}

Epistemologically value chain perspective can be traced back to the strategic planning. It has been the driver to the sustainability with a continuous aggregation and disaggregation for the upgradation and innovation in the firms. It has provided for the synergetic strength to sustainability of the firm sourcing out for the competitive advantage. The sustainability is driven by the balanced integration of environmental stewardship, social responsibility and economic prosperity. In the dynamic complexities of the business the firms need to command a management competency, which is largely dependent on employee know-how, external co-operation skills creation of a collective mind, organizational commitment, stimulation of the organizational learning process, organizational reputation, speed and flexibility in the design of new products or services. The value chain thus provides for a descriptive construct and thus a heuristic framework for the generation of data across the linkages.

However one cannot ignore that the term Value Chain includes both heuristic and analytical competencies. The values chain thus identifies the network and the causal effect relationship once the relationships are well structured. The Value chain plays a key role in the identification of sources and the scope of system competencies which in turn thus helps in the identification of the inflow and outflow of goods and services. Value chain provides for the alignment of the identified sources, linkages and the chosen generic strategy with the environmental stewardship, social responsibility and economic prosperity ensuring the sustainable development.

\section{References:}

1. Barney, J. (1991), "Firm Resources and Sustained Competitive Advantage." Journal of Management, Vol.17, No.1, pp. 99-120.

2. Beamon, B. M. (1999), "Designing the green supply chain", Logistics Information Management, Vol.12, No. 4, pp. 332-342.

3. Corso M., Martini A., Paolucci E. and Pellegrini L. (2001), "Knowledge management in product innovation: an interpretative review", International Journal of Management Reviews, Vol. 3, No.4, pp. 341-352.

4. Coyne, K. P. (1986), "Sustainable Competitive Advantage-what it is and what it isn't", Business Horizons, Vol. 29, No., pp. 54-61.

5. Cusumano, M. A. and Takeishi A. (1991), "Supplier relations and management: A survey of Japanese, Japanese-transplant, and U.S. auto plants", Strategic Management Journal, Vol.12, No.8, pp. 563-588.

6. Dyer, J. H. and Singh H. (1998). "The relational view: cooperative strategy and sources of inter organizational competitive advantage", Academy of Management Review, Vol. 23, No.4, pp. 660679.

7. Edvinsson, L. and Malone, M.S., (1997), “Intellectual Capital: Realizing your Company's True Value by Finding its Hidden Brainpower", New York, NY: Harper Business.

8. Elkington J., (2006), "Governance for Sustainability”, Corporate Governance, Vol.14, No.6, pp. 522-529

9. Eng Teck-Yong, (2005), "The effects of learning on relationship value in a business network context", Journal of Business-to-Business Marketing, Vol. 12, No.4, pp. 67-101

10. Fearne Andrew and Martinez Marian Garcia (2012), "Dimensions of sustainable value chains: implications for value chain analysis", Supply Chain Management: An International Journal, Vol.17, No.6, pp.575-581.

11. Galbraitfi, C. and Schendel D., (1983), "An empirical analysis of strategy types" Strategic Management Journal, Vol. 4, No.1 pp. 153-173. 
International Journal of Managing Value and Supply Chains (IJMVSC) Vol.4, No. 2, June 2013

12. Gulati, R., Nohria, N. and Zaheer, A. (2000), "Strategic networks", Strategic Management Journal, Vol.21, No.1, pp.203-215.

13. Hall, R. (1993), "A framework linking intangible resources and capabilities to sustainable Competitive advantage", Strategic Management Journal, Vol. 14, No.8, pp. 607 - 618

14. Hayton J. C. (2005), "Competing in the new economy: the effect of intellectual capital on corporate entrepreneurship in high-technology new ventures", R\&D Management, Vol.35, No.2, pp.137-155

15. Hergert M. \& Morris D., (1989), "Accounting data for value chain analysis", Strategic Management Journal, Vol. 10, No.12 pp. 175-188

16. Kleindorfer P.R ,Singhal K, Wassenhove L.K.N, (2005), "Sustainable operations management", Production and Operations Management, Vol. 14, No.4, pp. 482-492

17. McEvily, B. and Zaheer, A. (1999), "Bridging ties: a source of firm heterogeneity in competitive capabilities", Strategic Management Journal, Vol.20, No.12, pp. 1133-1156

18. Mudambi R. \& Helper S. (1998), "The close but adversarial model of supplier relations in the U.S. Auto industry", Strategic Management Journal, Vol. 19, No.8, pp775-792

19. Nonaka, I; Toyama, R; Nagata, A. (2000), "A firm as a knowledge-creating entity: a new perspective on the theory of the firm", Industrial \& Corporate Change, Vol. 9, No. 1, pp.1-20

20. Placet M., Anderson R. and Fowler K. M.,(2005), "Strategies for sustainability", Resource Technology Management, Vol. 48, No.5, pp. 32-41

21. Porter, M. E. (1985), “Competitive Advantage: creating \& sustaining superior performance”, Free press, New York.

22. Prahalad, C. K. and Hamel G. (1990), "The core competence of the corporation" Harvard Business Review, Vol.68, No.3, pp. 79-91

23. Rose, E.L. \& Ito, K. (1996), "Knowledge creation through the internal information market: an integration of total quality management", Quality Management Journal, Vol.3, No.3, pp. 87- 102.

24. Sanz-Valle R., Sabater-Sdnchez R. and Aragon-Sdnchez A. (1999), "Human resource management and business strategy links: an empirical study", The International Journal of Human Resource Management, Vol. 10, No.9, pp. 655-671

25. Savolainen, T. (2000), "Leadership Strategies for gaining business excellence through total quality management: a Finnish case study", Total Quality Management, Vol.11, No.2 pp. 211- 226.

26. Tan Jason \& Zailani Suhaiza, (2009), "Green value chain in the context of sustainability development and sustainable competitive advantage: A conceptual framework", International Journal of Business Insights \& Transformation, Vol.3, No1, pp. 41-50

27. Uzzi, B. (1996). "The sources and consequences of embeddedness for the economic performance of organizations: the network effect", American Sociological Review, Vol.61, No.4, pp. 674-98

28. World Commission on Environment and Development, (1987) "Our Common Future" Oxford: Oxford University Press

29. Wright, P.M., McMahan, G.C. and McWilliams, A., (1994), "Human Resources and Sustained Competitive Advantage: A Resource-based Perspective", International Journal of Human Resource Management, Vol.5, No.2, pp. 301-26. 